\title{
Transfer of seston lipids during a flagellate bloom from the surface to the benthic community in the Weddell Sea
}

\author{
SERGIO ROSSI ${ }^{1}$, ENRIQUE ISLA ${ }^{2}$, ALFREDO MARTÍNEZ-GARCÍA ${ }^{3}$, \\ NÚRIA MORALEDA ${ }^{1}$, JOSEP-MARÍA GILI ${ }^{2}$, ANTONI ROSELL-MELÉ ${ }^{1,4}$, \\ WOLF E ARNTZ ${ }^{5}$, DIETER GERDES ${ }^{5}$ \\ ${ }^{1}$ Environmental Science and Technology Institute, Autonomous University of Barcelona, Campus UAB s/n, Barcelona \\ 08193, Spain. E-mail: sergio.rossi@uab.cat \\ ${ }^{2}$ Institut de Ciències del Mar (CSIC), Passeig Marítim de la Barceloneta 39-47, Barcelona 08003, Spain. \\ ${ }^{3}$ Geologisches Institut NO G 55, Sonneggstrasse 5, 8092 Zürich, Switzerland. \\ ${ }^{4}$ Institució Catalana de Recerca i Estudis Avançats (ICREA), Barcelona, Catalonia, Spain. \\ ${ }^{5}$ Alfred Wegener Institute for Polar and Marine Research, Columbusstrasse, 27568 Bremerhaven, Germany.
}

SUMMARY: Total lipid and fatty acid concentrations were studied in a late spring-early summer flagellate-dominated bloom in the Weddell Sea. These indicators were considered a good tool for assessing the quality of organic matter settling from surface to deep-water layers (epibenthic water layers). The results showed different patterns between the early (11-15 December 2003) and the late sampling period (18-27 December 2003) at all studied depths (5 m, $50 \mathrm{~m}$ and near-bottom water layers). Low phytoplankton biomass (mainly flagellates) in the first half of the study corresponded to low total lipid and fatty acid concentrations. In the second sampling period a spring bloom (mainly flagellates and diatoms) was detected, increasing the total lipid and fatty acid concentrations in the water column. The amount of settling organic matter from surface waters to the near-bottom water layers was high, especially in the late sampling period. Trophic markers showed evidence of a sink of available organic matter rich in quality and quantity, especially in terms of polyunsaturated fatty acids, for benthic organisms from surface layers to bottom layers in only a few days. The importance of studying short-time cycles in order to detect organic matter availability for benthic biota in view of the pulse-like dynamics of primary production in Antarctic waters is discussed.

Keywords: Antarctica, seston, lipids, fatty acids, benthic-pelagic coupling, available food.

RESUMEN: TRANSFERENCIA DE LÍPIDOS DEL SESTON DURANTE UNA FLORACIÓN ALGAL DE FLAGELADOS DESDE LA SUPERFICIE HASTA EL BENTOS EN EL MAR DE WEDDELL. - Se estudió en el mar de Weddell la concentración de lípidos totales y ácidos grasos en una floración algal de flagelados durante un periodo comprendido entre finales de primavera y principios de verano. Estos dos indicadores (lípidos y ácidos grasos), se consideraron adecuados para describir la calidad de la materia orgánica depositada desde la superficie al fondo (aguas cercanas al bentos marino). Los resultados mostraron un patrón diferenciado entre el principio ( 11 al 15 de Diciembre) y el final ( 18 al 27 de Diciembre) del periodo de muestreo en todas las profundidades analizadas ( 5 metros, 50 metros y fondo). A la baja biomasa detectada (principalmente flagelados) en la primera parte del estudio correspondió a una concentración baja de lípidos y ácidos grasos. En el segundo periodo, se detectó una floración primaveral (compuesta principalmente por flagelados y diatomeas) que hizo incrementar la concentración de ácidos grasos y lípidos totales en la columna de agua. La caída de materia orgánica disponible para los organismos del fondo fue alta, sobre todo en la última fase del estudio y en coincidencia con la floración algal. Los marcadores, en especial los ácidos grasos poliinsaturados, mostraron un hundimiento relevante de materia disponible para los organismos del fondo en pocos días. En este artículo se discute la importancia de considerar los ciclos intensos de muestreo para detectar la caída en forma de pulsos del alimento disponible provenientes de la producción primaria de superficie para la comunidad bentónica y pelágica en aguas Antárticas.

Palabras clave: Antártida, seston, lípidos, ácidos grasos, acoplamiento bento-pelágico, alimento disponible. 


\section{INTRODUCTION}

Benthic-pelagic coupling is one of the main processes that explain the carbon cycle in the ocean (Gili et al. 2001, Smith et al. 2006). In the Southern Ocean, there is a marked seasonality in primary productivity due to light constraints (i.e. a long summer irradiance period contrasting with a long, dark winter period) that force the concentration of an intense pulse of organic matter in the austral spring-summer period in surface waters (Cripps and Clarke 1998). This high productivity promotes a rich available food content in marine sediments that persists for longer periods because of low degradation rates due to low temperatures $\left(0^{\circ} \mathrm{C}\right.$ to $\left.-2^{\circ} \mathrm{C}\right)$, fuelling the benthos during the whole year (Gutt et al. 1998, Mincks et al. 2005, Isla et al. 2006a, Isla et al. 2011). Primary produced material sometimes reaches the sea floor almost intact, despite the intense zooplankton grazing (von Bodungen et al. 1988, Cripps and Clarke 1998, Isla et al. 2009). Diatom aggregates and faecal pellets may reach the bottom within hours or a few days, depending on the main currents and the depth of the continental shelf (Thomas et al. 2001, Isla et al. 2006b, Isla et al. 2009), which in the Weddell Sea is unusually deep (200-500 m, Gili et al. 2006a). The quantity and quality of organic matter available during spring and summer blooms for the benthic organisms has been inferred but never directly measured.

The Weddell Sea is one of the most productive areas of the white continent (von Bodungen et al. 1988, Bathmann et al. 1991, Grossman et al. 1996). Below the seasonal pack ice, a rich benthic community with a high biodiversity and biomass has been described (Gutt and Starmans 1998, Gutt 2000, Teixidó et al. 2002, Gerdes et al. 2008). This community is fuelled by the seasonal phytoplankton blooms (Gili et al. 2001, Gili et al. 2009). It has recently been demonstrated that 1) in autumn there is a high lipid concentration in the surface sediments (Isla et al. 2006a), 2) there is an effective lateral transport that re-suspends and redistributes the available food (Isla et al. 2006b), and 3) the particle flux of a spring-summer bloom (under specific physical conditions) may be fast (Isla et al. 2009). Furthermore, the blooms produced (not necessarily diatoms) are grazed by crustacean zooplankton, depending on the water column stratification and the wind intensity and direction (Caron et al. 2000, Michels et al. 2012). In this context, one of the main questions that remain unanswered during the bloom conditions is how the organic matter is transferred to the bottom.

Total lipids in general, and fatty acids in particular, are useful indicators of the quality and the quantity of available food (Parrish 1988, Cripps and Clarke 1998, Grémare et al. 2002, Rossi et al. 2003, Rossi and Fiorillo 2010). Fatty acids are markers of the quality of phytoplankton material from the surface primary production when it is settling onto the bottom (Howell et al. 2003, Suhr et al. 2003, Parrish et al. 2005) and when the microphytoplankton has been quantified it may be related to the main groups which dominate algae production (Reuss and Poulsen 2002). The analysis of these variables in the water column will give a clearer idea of the quality and the processes that provide available particulate organic matter (POM) to the benthos.

The main objective of this study is to measure the quality of seston that could be available for pelagic and benthic organisms in surface and near-bottom water layers during the spring-summer bloom season. For this reason, we calculated the quality of seston (its lipid concentration) in the water column of the Weddell Sea (from the surface to the bottom water layers) during a spring-summer bloom The results are related to previous studies performed during the same period (December 2003, Gerdes et al. 2008, Isla et al. 2009, Pasternak et al. 2009, Isla et al. 2011, Michels et al. 2012). We also compared the early data of the spring bloom with the lipids concentrated in the organic matter within the ice, trying to relate ice POM with seston POM along the studied bloom.

\section{MATERIALS AND METHODS}

The study was carried out in the Weddell Sea, at $70^{\circ} 40.558^{\prime} \mathrm{S}$ and $10^{\circ} 43.698^{\prime} \mathrm{W}$ (Fig. 1, Gerdes et al. 2008, Isla et al. 2009, Michels et al. 2012). The station was regularly visited by R/V Polarstern between 9 and 28 December 2003, enabling water sampling almost every day. The water depth varied between 443 and $470 \mathrm{~m}$ (Table 1).

\section{Sampling procedures}

From the 15 CTD-fluorescence casts made during this monitoring with the calibrated Sea-Bird 911plus CTD attached to a rosette water sampler (Michels et al. 2012), 7 were used to perform the total lipid and fatty acid seston analyses (see above). Seston samples were recovered from filtered sea water collected with the 12-L Niskin bottles of the rosette. The water layers under study were surface waters $(5 \mathrm{~m}$ depth, always below the maximum ice thickness), maximum fluorescence layers (50-65 $\mathrm{m}$ depth) and bottom layers (up to $470 \mathrm{~m}$ depth, 1.5-2 $\mathrm{m}$ above the sea floor). Each replicate was taken from a different Niskin bottle. Water samples were kept in the dark at $4^{\circ} \mathrm{C}$ until filtration. The time between water collection and water filtration never exceeded 60 minutes.

The water was filtered using $0.7-\mu \mathrm{m}$ Whatman $\mathrm{GF} / \mathrm{F}$ filters (pre-combusted at $450^{\circ} \mathrm{C}$ for 8 hours, 5000 $\mathrm{mL}$ per filter). A total of 3 filters were sampled at each depth for the total lipids, and additional 2-3 filters were used for fatty acid analysis. It is usually considered that this mesh retains mainly phytoplankton, faecal pellets, microzooplankton and half of the bacterial biomass (Lee and Fuhrman 1987, Chavez et al. 1995). Large zooplankton organisms (detectable by the naked eye) were removed from the filters with forceps. The filters were immediately stored in liquid nitrogen until subsequent lyophilization in a Heto Maxi Dry Lio for 

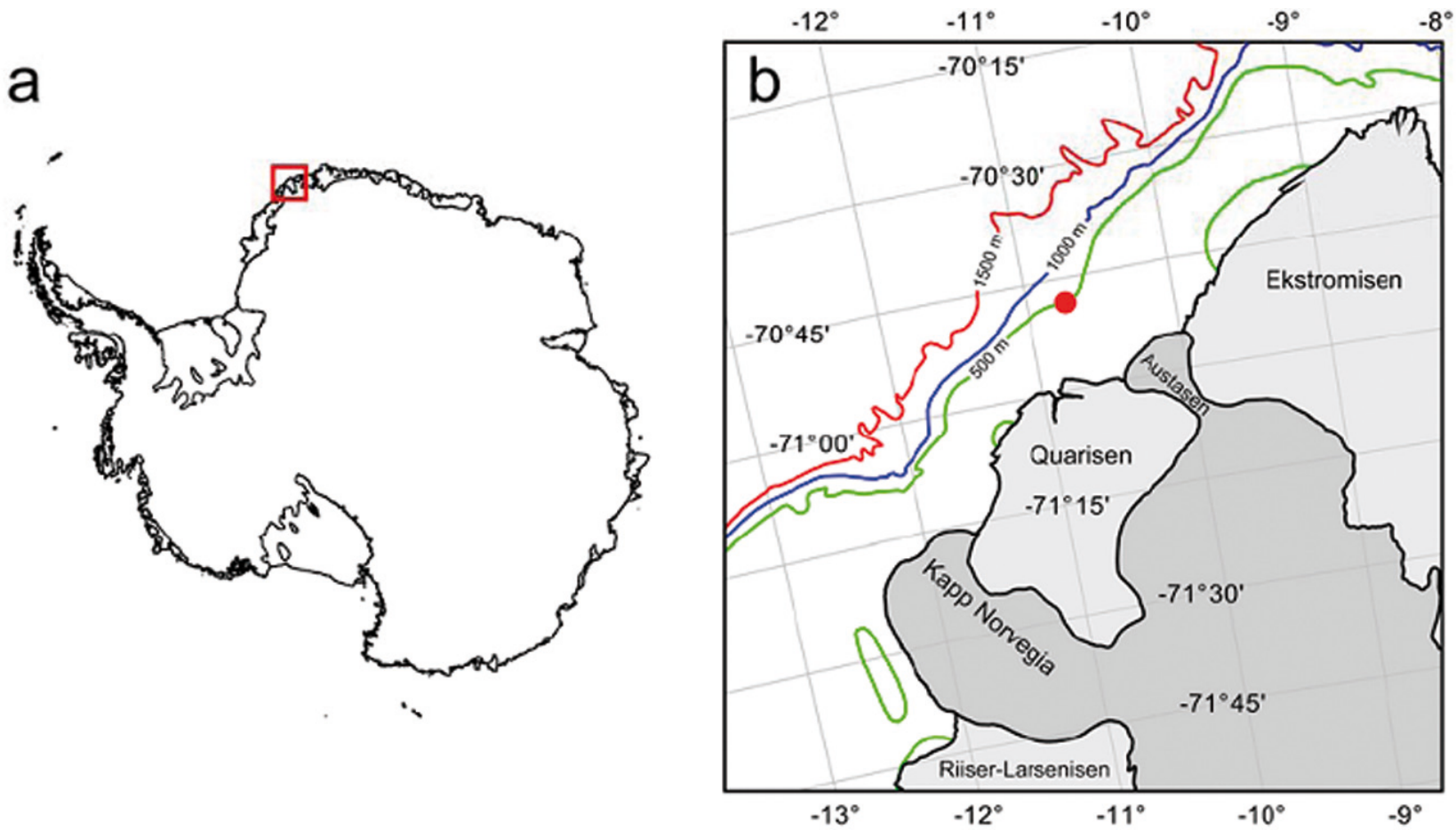

FIG. 1. - (a) Map of the Weddell Sea showing the location of the study area (rectangle). (b) detailed map of the area marked by the red rectangle in (a) showing the location of the quasi-permanent station (dot) on the eastern Weddell Sea shelf.

TABLE 1. - Sampling list: dates, corresponding RV Polarstern station number and maximum depth. In the deepest water layers, samples were collected 1.5-2 metres above the bottom.

\begin{tabular}{ccc}
\hline Sampling date & $\begin{array}{c}\text { RV Polarstern Station } \\
\text { number }\end{array}$ & $\begin{array}{c}\text { Max sampling } \\
\text { depth }(\mathrm{m})\end{array}$ \\
\hline 11 Dec 2003 & PS65-127 & 443 \\
14 Dec 2003 & PS65-156 & 449 \\
15 Dec 2003 & PS65-168 & 456 \\
18 Dec 2003 & PS65-204 & 456 \\
20 Dec 2003 & PS65-230 & 454 \\
22 Dec 2003 & PS65-241 & 460 \\
27 Dec 2003 & PS65-260 & 470 \\
\hline
\end{tabular}

8 hours. After that, the filters were stored at $-80^{\circ} \mathrm{C}$ during the rest of the trip pending analysis.

At the same fixed station, a block of melting ice was picked up on 15 December. Two different parts were sampled, the underneath ice (called brown ice, the first 3-5 cm, following the description of Fahl and Kattner 1993), and ice 15 centimetres above the submersed surface (called white ice following the description of Fahl and Kattner 1993). Three pieces of the ice block were carefully sampled with a stainless steel picket. The ice was melted at $4^{\circ} \mathrm{C}$, the water gently mixed, and $100 \mathrm{~mL}$ of each replicate was filtered (GF/F filters, as described above) for the total lipids, and $100 \mathrm{~mL}$ of each replicate was filtered for the fatty acid analysis (algal concentration was much higher than in the water column).

\section{Total lipids}

The three replicates of filtered water of $5000 \mathrm{~mL}$ each for total lipids were analysed using the Barnes and
Blackstock, (1973) spectrophotometric procedure. Filters were extracted in chloroform-methanol $(2: 1 \mathrm{v} / \mathrm{v})$. The extract was dried and sulphuric acid and vanillin wasused to complete the colorimetric method. Sample and test blanks were performed during the procedure to control the interference of filter glass fibre particles, and cholesterol was used as a standard (Isla et al. 2010, Rossi and Fiorillo 2010, Isla et al. 2012). There are concerns about the use of this methodology (Barnes and Blacksock 1973) with seston samples (potential interference in glass fibre filters). We decided to make a test by measuring near-bottom seston lipids with the present method (four filters), contrasting the results with the methodology of Folch et al. (1957) (four filters filtering $5 \mathrm{~L}$ for each filter) to quantify possible errors. No significant difference was found between the two methods in the tested filters (Barnes and Blackstock (1973) method $=73 \pm 9 \mu$ lipids $L^{-1}$, Folch et al. (1957) method $=65 \pm 17 \mu \mathrm{g}$ lipids $\mathrm{L}^{-1}$, one-way ANOVA, $\mathrm{F}_{1,7}=0.4714, P=0.649$ ).

\section{Fatty acid analysis}

Freeze-dried filters were extracted by microwaveassisted extraction $\left(5 \mathrm{~min}\right.$ at $70^{\circ} \mathrm{C}$ ) with $10 \mathrm{ml}$ of $3: 1$ dichloromethane-methanol, using 2-octyldodecanoic acid and $5 \beta$-cholanic acid as internal standards. Among the tested methods, the microwave oven method has been identified as the simples, easiest and most effective for microalgae lipid extraction (Kornilova and Rosell-Melé 2003, Gómez-Brandón et al. 2008). 
First, to test the potential differences between this method and others previously performed successfully with seston filters (see Rossi et al. 2006, Rossi et al. 2008), we compared four filters with conventional extraction with another four filters undergoing microwave extraction (5 L of Mediterranean seawater filtered for each sample). The result showed a slight non-significant difference [Rossi et al. (2006) method $=30 \pm 5 \mu \mathrm{g}$ fatty acid $\mathrm{L}^{-1}$; microwave oven method $=$ $29 \pm 6 \mu \mathrm{g}$ fatty acid $\mathrm{L}^{-1}$; one-way ANOVA, $\mathrm{F}_{1,7}=0.0661$; $P=0.806]$. We also tested four different polyunsaturated fatty acids (PUFA) to see whether there was a significant degradation of some monounsaturated fatty acids (MUFA) and PUFA, but we found no differences in the proportions (see Table S1 Electronic Supplementary Material, ESM).

Once it had been demonstrated that this microwaveassisted methodology was not interfering with the results (see also Rossi and Fiorillo 2010, Rossi et al. 2012), samples were subsequently extracted with the procedure of Ruiz et al. (2004). The extract was taken to near dryness in a centrifugal vacuum concentrator at a constant temperature and fractionated by solid phase extraction according to Ruiz et al. (2004). Briefly, the sample was re-dissolved in $0.5 \mathrm{~mL}$ of chloroform, and eluted through a 500-mg aminopropyl mini-column (Waters Sep-Pak® Cartridges) previously conditioned with $4 \mathrm{~mL}$ of $n$-hexane. The first fraction was eluted with $3 \mathrm{~mL}$ of chloroform:2-propanol (2:1), and the fatty acids were recovered with $8.5 \mathrm{~mL}$ of diethyl ether:acetic acid (98:2). The fatty acid fraction was methylated using a solution of methanol/ $\mathrm{BF}_{3}(20 \%$ of $\mathrm{BF}_{3}$ diluted in methanol) heated at $90^{\circ} \mathrm{C}$ for $1 \mathrm{~h}$. The reaction was quenched with $4 \mathrm{~mL}$ of water saturated with $\mathrm{NaCl}$. The methyl esters of FA were recovered by extracting twice with $3 \mathrm{~mL}$ of $n$-hexane. The combined extracts were taken to near dryness, re-dissolved with $1.5 \mathrm{~mL}$ of chloroform, eluted through a glass column filled with $\mathrm{Na}_{2} \mathrm{SO}_{4}$ to remove residual water, taken to dryness under a gentle nitrogen flux, and stored at $-20^{\circ} \mathrm{C}$ until analysis. The organic extracts were redissolved in $30 \mu \mathrm{L}$ of isooctane and analysed by gas chromatography (GC). GC analysis was performed in splitless injection mode using a Thermo Trace GC instrument fitted with a flame ionization detector, and a DB-5 Agilent column (30 m length, $0.25 \mathrm{~mm}$ internal diameter and $0.25 \mu \mathrm{m}$ phase thickness). Helium was used as a carrier gas at a constant flow of $33 \mathrm{~cm} \mathrm{~s}^{-1}$. The oven temperature was programmed to increase from $50^{\circ} \mathrm{C}$ to $320^{\circ} \mathrm{C}$ at $10^{\circ} \mathrm{C} \mathrm{min}^{-1}$, and held at $320^{\circ} \mathrm{C}$ for 17 minutes. Injector and detector temperatures were kept constant at $300^{\circ} \mathrm{C}$ and $320^{\circ} \mathrm{C}$, respectively, throughout the analysis.

Previous qualitative analyses were performed by GC-MS 7890a-5975C (Agilent Technologies). The oven temperature was programmed at $50^{\circ} \mathrm{C}$ for $1 \mathrm{~min}$, $15^{\circ} \mathrm{C} \mathrm{m^{-1 }}$ to $150^{\circ} \mathrm{C}$ for $0 \mathrm{~min}, 1.5^{\circ} \mathrm{C} \mathrm{min}{ }^{-1}$ to $200^{\circ} \mathrm{C}$

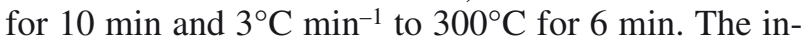
jector was $300^{\circ} \mathrm{C}$. MS conditions were the following: transfer line $320^{\circ} \mathrm{C}$ and ion source $250^{\circ} \mathrm{C}$ and quadrupole $150^{\circ} \mathrm{C}$. Ionization mode was electron impact at $70 \mathrm{eV}$. Mass spectra were acquired by scanning the mass range 50-550 (2 $\mu \mathrm{L}$ injection in a DB5-MS $30 \mathrm{~m}$ $\times 250 u \mathrm{~m} \times 0.25 \mu \mathrm{m}$ column). Fatty acid methyl esters (FAMEs) were identified by comparing their retention times with those of standards (37 FAME compounds, Supelco® Mix C4-C24). The FAMEs were quantified by integrating peak areas and corrected taking into account the recoveries calculated from the internal standards. The reproducibility of the procedure was evaluated by injecting blanks and internal standards at different concentrations. A blank sample was analysed in every batch of 14 samples to monitor background levels of FAME during the analysis.

\section{RESULTS}

\section{Seston total lipid and fatty acid concentrations}

The total lipid and fatty acid concentration trends at $5 \mathrm{~m}, 50 \mathrm{~m}$ and bottom depths are shown in Table 2 , and the relative proportions (\%) of fatty acids from total lipids are shown in Figure 2A-G. In general, the fatty acid proportion related to total lipid concentration increased over the study period, following the bloom development. Figure 3 shows the PUFA, MUFA and Saturated Fatty Acid (SAFA) proportions. The PUFA were fairly constant over the entire sampling period at the different depths, with the exception of the first two sampling days (see Table 2).

\section{Fatty acid biomarkers}

Tables S2 and S3 (Electronic Supplementary Material) shows the fatty acid biomarker proportion at different depths over the study period.

The diatom markers [C16:1(n-7), C16:1(n-9) and C16:x unsaturated fatty acids, cf. Dalsgaard et al. 2003 for a review) varied in surface waters ( $5 \mathrm{~m}$ depth) at the beginning of the sampling period (Tables S2 and S3 ESM), but remained almost constant from 18 December to the end of the bloom. The C16:1(n-7) was almost absent on 11 December, showed higher values on 14 and 15 December and reached values above $10 \%$ on the following days. The sum of mono- and polyunsaturated derivatives of the $\mathrm{C} 16$ fatty acids also increased in concentration from 14 to 27 December, with a peak on 18 December. C20:5 (n-3), also considered as a diatom marker (Dalsgaard et al. 2003), showed moderate to high values depending on the sampling period and the depth. No relationship was observed between the C16:1(n-7) and the C20:5 (n-3) markers at all depths and sampling days $\left(\mathrm{R}^{2}=0.2, P>0.5 ; \mathrm{N}=21\right)$.

At the beginning of the sampling period, $\mathrm{C} 16: 1(\mathrm{n}-7)$ showed low values (see supplementary material Tables S2 and S3), suddenly increasing at $50 \mathrm{~m}$ depth from the $7.8 \%$ measured on 11 December to $25.9 \%$ on 14 December. After this peak, the C16:1(n-7) values showed 

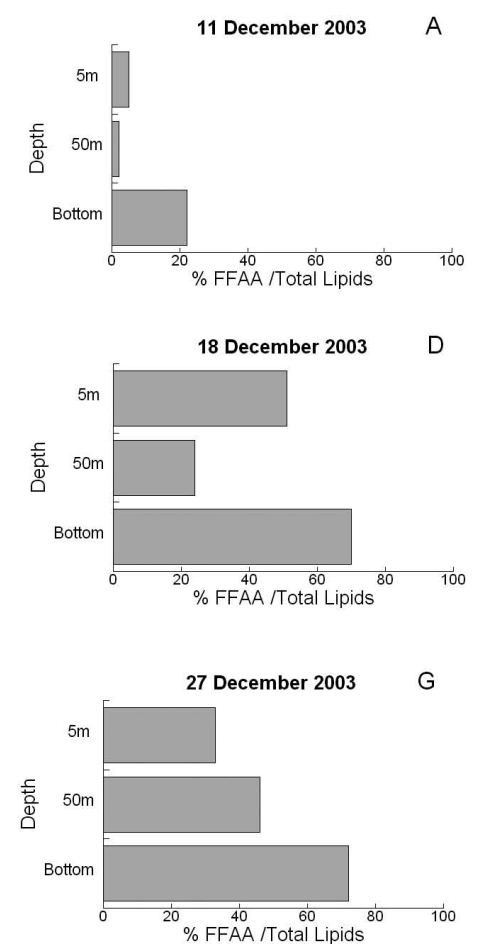

FIG. 2. - Fatty acid proportion (\%) of the total lipid concentration at the three sampled depths $(5,50$ and around $450 \mathrm{~m})$ in the water column from 11 to 27 December 2003.

TABLE 2. - Total lipid and fatty acid concentration $\left(\mu \mathrm{g} \mathrm{L} \mathrm{L}^{-1}\right)$ in the water column $(5 \mathrm{~m}, 50 \mathrm{~m}$ and near-bottom water layers) during the sampling period (Mean \pm SD). SD, standard deviation. SAFA, saturated fatty acids; MUFA, monounsaturated fatty acids; PUFA, polyunsaturated fatty

\begin{tabular}{|c|c|c|c|c|c|c|c|}
\hline Day & $\begin{array}{c}\text { Total lipids } \\
\mu \mathrm{g} \mathrm{L}^{-1}\end{array}$ & SD & $\begin{array}{c}\text { Fatty acids } \\
\qquad \mu \mathrm{g} \mathrm{L}^{-1}\end{array}$ & SD & $\begin{array}{l}\text { PUFA } \\
\mu \mathrm{g} \mathrm{L}^{-1}\end{array}$ & $\begin{array}{l}\text { MUFA } \\
\mu \mathrm{g} \mathrm{L}^{-1}\end{array}$ & $\begin{array}{l}\text { SAFA } \\
\mu \mathrm{g} \mathrm{L}^{-1}\end{array}$ \\
\hline \multicolumn{8}{|l|}{$11 / 12 / 2003$} \\
\hline $5 \mathrm{~m}$ & 81.1 & 7.2 & 3.8 & 0.9 & 0.7 & 0.7 & 2.4 \\
\hline $50 \mathrm{~m}$ & 64.1 & 5.4 & 1.2 & 0.7 & 0.8 & 0.2 & 0.2 \\
\hline Bottom & 21.3 & 11.3 & 4.7 & 0.4 & 1.8 & 0.4 & 2.6 \\
\hline \multicolumn{8}{|l|}{$14 / 12 / 2003$} \\
\hline $5 \mathrm{~m}$ & 31 & 6.3 & 3.3 & 5.2 & 0.62 & 0.95 & 1.71 \\
\hline $50 \mathrm{~m}$ & 63.1 & 4.3 & 3.5 & 0.9 & 1.36 & 1.01 & 1.12 \\
\hline Bottom & 12.4 & 2.9 & 2.3 & 1.5 & 1.1 & 0.7 & 0.6 \\
\hline \multicolumn{8}{|l|}{$15 / 12 / 2003$} \\
\hline $5 \mathrm{~m}$ & 109.1 & 16.4 & 43.1 & 5.6 & 13.4 & 8.2 & 21.5 \\
\hline $50 \mathrm{~m}$ & 84.1 & 12.9 & 40.2 & 6.3 & 16.5 & 6.8 & 16.9 \\
\hline Bottom & 37.3 & 7.6 & 4.2 & 1.0 & 2.1 & 0.7 & 1.4 \\
\hline \multicolumn{8}{|l|}{$18 / 12 / 2003$} \\
\hline $5 \mathrm{~m}$ & 105.1 & 10.6 & 53.5 & 7.0 & 20.9 & 11.8 & 19.8 \\
\hline $50 \mathrm{~m}$ & 123.5 & 9.7 & 29.7 & 39.7 & 10.4 & 5.4 & 14.0 \\
\hline Bottom & 70.3 & 10.3 & 49.0 & 17.9 & 21.1 & 8.3 & 19.1 \\
\hline \multicolumn{8}{|l|}{$20 / 12 / 2003$} \\
\hline $5 \mathrm{~m}$ & 26.2 & 4.9 & 15.3 & 1.4 & 6.6 & 2.6 & 6.1 \\
\hline $50 \mathrm{~m}$ & 42.6 & 4.7 & 9.9 & 1.1 & 3.3 & 1.7 & 4.8 \\
\hline Bottom & 15.6 & 3.9 & 10.8 & 3.7 & 4.0 & 1.7 & 5.0 \\
\hline \multicolumn{8}{|l|}{$22 / 12 / 2003$} \\
\hline $5 \mathrm{~m}$ & 51.6 & 8.1 & 20.2 & 6.5 & 8.5 & 4.0 & 7.7 \\
\hline $50 \mathrm{~m}$ & 46.3 & 8.9 & 21.3 & 11.1 & 9.2 & 3.6 & 8.7 \\
\hline Bottom & 27.9 & 6.9 & 10.1 & 1.6 & 4.1 & 1.9 & 4.0 \\
\hline \multicolumn{8}{|l|}{$27 / 12 / 2003$} \\
\hline $5 \mathrm{~m}$ & 192.3 & 24.8 & 62.7 & 6.4 & 21.3 & 15.1 & 24.5 \\
\hline $50 \mathrm{~m}$ & 120.1 & 15.6 & 54.9 & 3.2 & 23.1 & 13.2 & 18.7 \\
\hline Bottom & 83.4 & 7.4 & 59.8 & 11.2 & 20.3 & 9.6 & 27.5 \\
\hline
\end{tabular}



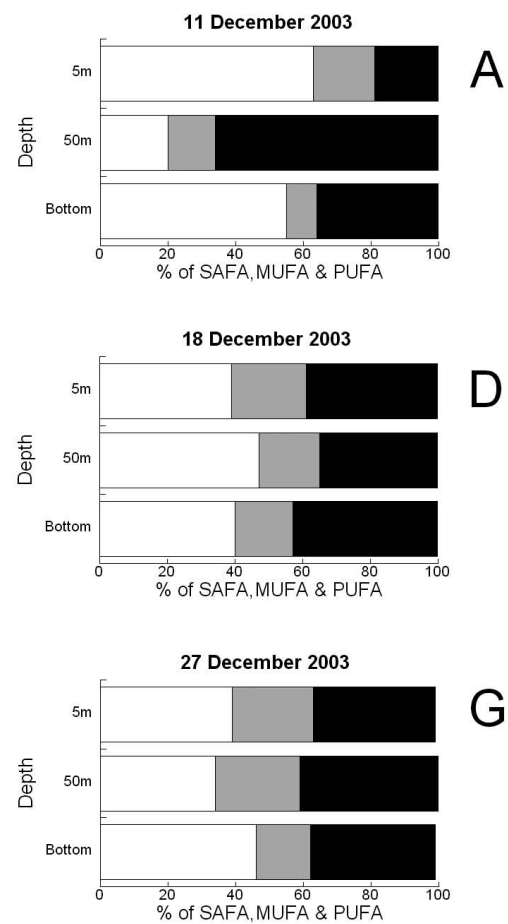
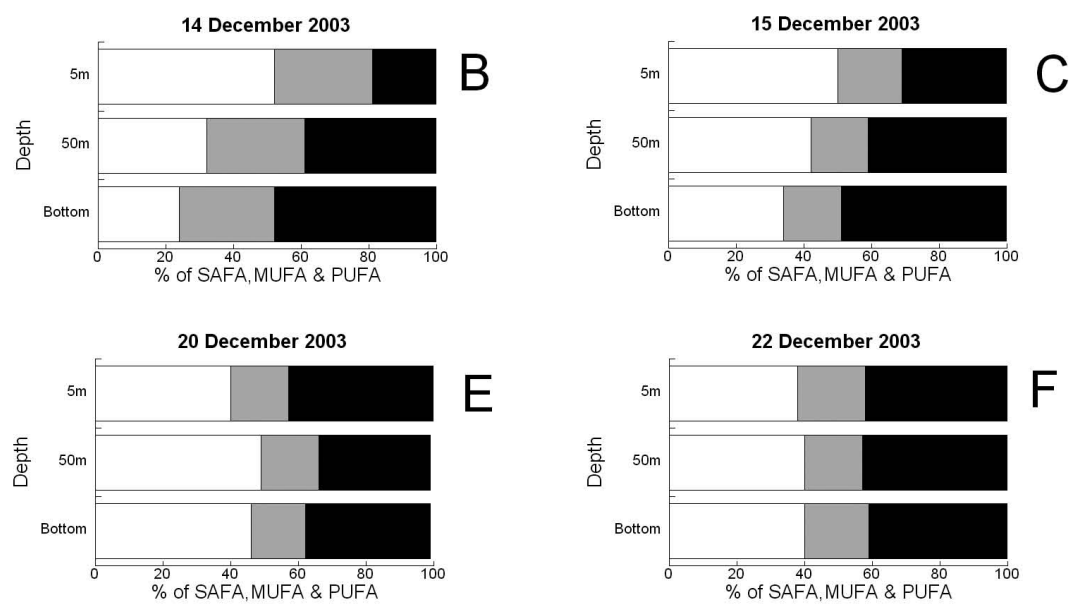

FIG. 3. - Relative abundance of saturated fatty acids (SAFAs, white), monounsaturated fatty acids (MUFAs, grey), and polyunsaturated fatty acids (PUFAs, black) (\%) at the three sampled depths $(5,50$ and around $450 \mathrm{~m})$ in the water column from 11 to 27 December 2003.

proportions above $10 \%$, except on 20 December, when it decreased to around $8 \%$. Compared with the surface waters, where other markers such as C16:1(n-9) and C16:4(n-3) were more important, the sum of monoand polyunsaturated derivatives of the C16 fatty acids was dominated by the presence of C16:1(n-7). The relationship of the $\mathrm{C} 16: 1(\mathrm{n}-7)$ marker and diatom proportion in surface waters was significant $[\mathrm{C} 16: 1(\mathrm{n}-7)$ $(\%)=1.31+0.15$ Diatoms $\left.(\%) ; \mathrm{R}^{2}=0.61, P<0.05 ; \mathrm{N}=6\right]$ (data from Michels et al. 2012). Also, the relationships between the other C16:x markers and the diatom proportion at $5 \mathrm{~m}$ depth were significant [C16:x (\%) $=6.36+0.14$ Diatoms $\left.(\%) ; \mathrm{R}^{2}=0.64, P<0.05 ; \mathrm{N}=6\right]($ data from Michels et al. 2012).

Flagellate markers C18:4(n-3) and C22:6(n-3) (Reuss and Poulsen 2002, Dalsgaard et al. 2003) were present throughout the sampling period (see Tables S2 and S3 ESM). C18:4(n-3) showed increasing values from the beginning to the end of the cycle, reaching stable proportions above $10 \%$ from 18 to 27 December. C22:6(n-3) showed low proportions well above $4 \%$ from 11 to 18 December. The relationship of the C18:4(n-3) marker and the flagellate proportion was significant in surface waters $[\mathrm{C} 18: 4(\mathrm{n}-3)(\%)=2.96+0.12$ flagellates (\%); $\left.\mathrm{R}^{2}=0.91, P<0.01 ; \mathrm{N}=6\right]$ (data from Michels et al. 2012).

The flagellate fatty acid C18:4(n-3) (see Tables S2 and S3 ESM) showed a higher proportion in nearbottom waters than at the surface throughout the study period, increasing from the beginning to the end of December. The C22:6 (n-3) marker had its maximum around 14 December (more than 23\%). During the rest of the period it remained stable between $3 \%$ and $5 \%$.

At $50 \mathrm{~m}$ depth, the diatom marker C16:1(n-7) resembled the bottom water pattern more than that at the surface (see Tables S2 and S3 ESM). The flagellate marker C18:4(n-3) also showed similar values at $50 \mathrm{~m}$ depth and near the bottom from 14 to 27 December. The C22:6(n-3) flagellate marker had very similar values at $50 \mathrm{~m}$ depth and in bottom waters, except on 14 December, when the concentration of this marker was almost one order of magnitude higher near the bottom than at $50 \mathrm{~m}$ depth.

The saturated fatty acid C18:0 and other monounsaturated fatty acids of the C18 family showed high values in surface waters, always above $10 \%$ and in some cases even above 20\%. C18:0 decreased from 11 to 15 December, and then increased again from 18 to 27 December.

\section{Total lipid and fatty acid concentration and proportions in sea ice}

Total lipid concentration showed almost one order of magnitude difference in brown ice as compared to white ice on 15 December 2003 (Fig. 4). Furthermore, the fatty acid concentration was $>3$ times higher in the brown ice. In the brown ice, fatty acids accounted for $35 \%$ of the total lipids, whilst in white ice they accounted for $42 \%$.

The different types of fatty acid also varied in proportions between brown ice and white ice (Table 
Total Lipids

Fatty Acids

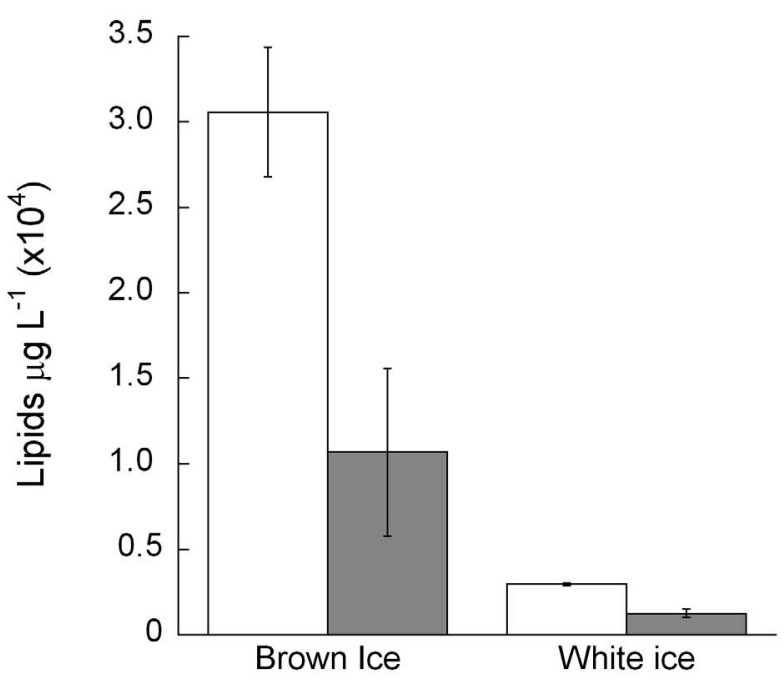

FIG. 4. - Total lipid and fatty acid concentrations $\left(\mu \mathrm{g} \mathrm{L}^{-1}\right)$ in "brown ice' (first 3-5 cm of the ice layer in contact with the sea water) and 'white ice' (ice layer $15 \mathrm{~cm}$ from the surface in contact with the sea water) from the sample picked up on 15 December.

TABLE 3. - Fatty acid composition (as a $\%$ of the total fatty acids) in the ice cores sampled on 15 December 2003 near the semi-permanent station of the Weddell Sea

\begin{tabular}{lcccc}
\hline Fatty Acids & $\begin{array}{c}\text { Brown Ice } \\
\text { (Mean) } \\
\text { N=3 }\end{array}$ & SD & $\begin{array}{c}\text { White Ice } \\
\text { (Mean) } \\
\text { N=3 }\end{array}$ & SD \\
\hline C14:0 & 3.2 & 0.5 & 16.6 & 0.3 \\
C16:1 (n-7) & 13.5 & 0.7 & 23.2 & 0.1 \\
C16:1 (n-9) & 0.7 & 0.2 & 5.3 & 0.0 \\
C16:4(n-3) & 7.6 & 0.8 & 8.2 & 1.5 \\
C16:0 & 28.2 & 1.9 & 26.3 & 1.6 \\
C17:0 & 0.3 & 0.1 & 0.0 & - \\
C18:4 (n-3) & 10.1 & 0.9 & 0.4 & 0.1 \\
C18:3(n-3) & 3.1 & 0.4 & 0.6 & 0.1 \\
C18:2(n-6) & 1.2 & 0.3 & 1.9 & 0.5 \\
C18:2 (n-4) & 0.0 & - & 1.7 & 0.1 \\
C18:1 (n-9) & 1.3 & 0.2 & 2.3 & 0.0 \\
C18:1 (n-7) & 0.0 & - & 1.0 & 0.3 \\
C18:0 & 9.9 & 1.7 & 0.7 & 0.5 \\
C20:5 (n-3) & 3.9 & 0.7 & 4.6 & 1.5 \\
C20:0 & 0.0 & - & 0.3 & 0.1 \\
C22:6 (n-3) & 5.2 & 0.5 & 0.0 & 0.0 \\
C24:1 & 1.6 & 0.2 & 0.0 & - \\
C24:0 & 0.3 & 0.0 & 0.0 & - \\
Other fatty Acids & 9.9 & & 6.9 & \\
PUFA & & & & \\
MUFA & 42.4 & & 24.8 & \\
SAFA & 18.4 & & 34.0 & \\
\hline
\end{tabular}

3). PUFA had a higher proportion in brown ice than in white ice; MUFA showed the opposite trend, and SAFA had similar proportions in both ice layers (around 45\%-50\%). The brown ice was dominated by biomarkers of flagellate origin (i.e. C18:4(n-3) around $12 \%$, and $\mathrm{C} 22: 6(\mathrm{n}-3)$ around $4 \%$ ); these biomarkers showed lower values in the white ice (i.e. C18:4(n-3) around $0 \%, \mathrm{C} 22: 6(\mathrm{n}-3)$ around $0 \%$, and $\mathrm{C} 18: 0$ around
1\%). C16:1(n-7) showed low values in the brown ice (around 13\%), but in the white ice it was two times higher, reaching more than 26\%. Other C16:x markers were also present in the white ice, as well as C14:0, which can also be considered as a diatom marker (Dalsgaard et al. 2003).

\section{DISCUSSION}

The present study deals with the quality of food for pelagic and benthic organisms via the total lipid and fatty acid concentrations, demonstrating an efficient transfer of organic matter after an algal bloom in which good quality seston is found throughout the water column and close to the seabed. The brown and white ice fatty acid signals found in the $15-\mathrm{cm}$ ice column can be associated with the algal presence in the water column (Michels et al. 2012). Underwood et al. (2010) showed clear differences within the first $15-20 \mathrm{~cm}$ of ice cores in extracellular polymeric substances and carbohydrate composition, due to the different physiological state of algae and the differences in algae community composition.

These differences in the dominant markers of algae in ice may, in part, be the cause of the clear asymmetry in the magnitude of the particle flux between the beginning and the end of the sampling period (Isla et al. 2009). During the first few days of December, a weak flux was detected in a near-bottom sediment trap, but after the high production phase in the second half of the month, the particle flux increased greatly. In fact, the total mass flux varied up to 60 -fold in only 3 days over the study period (Isla et al. 2009, Michels et al. 2012). Although the bloom that formed did not have a high organic matter concentration, such an increase is not surprising in Antarctic waters. Wind conditions seem to facilitate diatom sinking (Isla et al. 2009, Michels et al. 2012) and this group is probably more important than flagellates in the transfer of seston with good biochemical quality (i.e. richer in lipids and with more PUFA per mass unit).

Ice dynamics is one of the main forces structuring the pelagic ecosystem in the Southern Ocean, so the presence of ice can be associated with higher or lower productivity (von Bodungen et al. 1988, Batmann et al. 1991, Arrigo et al. 1998). The calm conditions between 19 and 22 December allowed the freshening and warming of the surface layer. This factor caused a marked water stratification, thus facilitating the increase in cell proliferation and explaining the increase in lipid concentration associated with diatom active cells (Isla $e t$ al. 2009, Michels et al. 2012). After that, the freshening reached its maximum values due to more intense ice break-up and mixing of fresher water from the upper layers (Isla et al. 2009). In this step, there was a progression in the flagellate biomass dominance over diatom cells coming from the sea ice, demonstrated by the shift in ice fatty acid markers. As mentioned above, ice composition is far from homogeneous, and it is 
possible that in the same ice core different layers were dominated by different groups that may also have a different physiological status (Underwood et al. 2010). Observations seem to indicate that this situation is probably common in various areas of the Weddell Sea.

\section{Dominant phytoplankton and biomarkers}

Flagellates were the dominant microphytoplankton group (by biomass) during the study period (other than Phaeocystis spp, Michels et al. 2012), a finding which is in accordance with the fatty acids found in the present study, especially C18:4(n-3) (see also Reuss and Poulsen 2002, Rossi et al. 2006, Rossi and Fiorillo 2010, Rossi et al. 2012). The good relationship between the proportions of organic carbon of the phytoplankton and $\mathrm{C} 18: 4(\mathrm{n}-3)$ clearly confirms this trophic marker as a flagellate component, whereas the weak relationship of C22:6(n-3) with the phytoplankton biomass ( $\mu \mathrm{gC}$ $\left.\mathrm{L}^{-1}\right)$ may be due to the low abundance of dinoflagellates (Michels et al. 2012).

Fatty acids of diatom origin were present in our analysis, especially in certain periods. Before the storm, the diatom carbon biomass at $5 \mathrm{~m}$ depth increased steadily, contributing almost $50 \%$ to overall phytoplankton carbon (Michels et al. 2012). This factor can be explained by the different concentrations of lipids depending on the physiological state of diatoms. Kuwata et al. (1993) showed that vegetative cells have less total lipids and fatty acids than resting spores. The increase in C16 unsaturated fatty acids is related to the increase in diatom biomass (Fraser et al. 1989, Hayakawa et al. 1996), but the quantity per cell may decrease when cells are growing, thus reducing the lipid content of cells as the bloom develops (Kuwata et al. 1993). Thus, on the basis of the fatty acid signal, diatoms seemed to undergo an increase in biomass during the sampling period. Flagellates seemed to have a more linear response, only depending on the bloom dynamics (i.e. more biomass, more lipids, because of the quite stable concentration of lipids per cell); however, they host fewer lipids per cell than diatoms (Reuss and Poulsen 2002). Hence, our results underline the important role that diatoms play in the transport of lipids to the seabed, though the may occasionally constitute a smaller biomass than that of flagellates. Taking into account the relatively high energy contents of lipids (Qiang et al. 2008), the difference implies that benthos strongly depends on diatom blooms to cope with the absence of pelagic production during the autumn-winter months.

In the present study, the proportion of PUFAs is quite constant during the second period of the sampling, being almost always below 50\% (Table 2, and Tables S2 and S3 Electronic Supplementary Material). In late spring, most of the settling POM may come from faecal pellets in this area (up to $90 \%$, particularly at the beginning of the blooms, when grazing is intense, von Bodungen et al. 1988). The presence of moderate-high levels of C18:0 suggests a significant contribution of the material coming from faecal pellets (Pasternak et al. 2009, Michels et al. 2012). It has been shown that the passage of phytoplankton through the zooplankton gut system may change fatty acids (toward a higher concentration of SAFA, Prahl et al. 1984), so part of the particles found in the present study may come from faecal pellets (Isla et al. 2009). However, in the light of the present results (moderate-high levels of MUFAs and PUFAs, especially in the second part of the sampling cycle, Table 3 and Fig. 3), the amount of phytoplankton assimilated by the zooplankton could be low in relation to the total diatom biomass present in the phytoplankton bloom.

The moderate-high level of unsaturated fatty acids found in the near-bottom water layers could be related to the sinking velocity of the particulate organic matter. The sinking velocity of material from the surface to the seafloor during the studied spring bloom was at least $34 \mathrm{~m}$ per day (Isla et al. 2009), which is slower than other sinking rates measured in the Antarctic (100$150 \mathrm{~m} \mathrm{day}^{-1}$ or $288 \mathrm{~m} \mathrm{day}^{-1}$, Lampitt 1985, Asper and Smith 2003). These results may imply that the environmental conditions in the southeastern Weddell Sea, (e.g. low temperature) potentiate the preservation of organic matter with good chemical quality for several days before it accumulates on the seabed, and also that there was low grazing pressure throughout the water column over the continental shelf.

\section{Seston quality and benthic-pelagic coupling}

In the present study, if the lowest values of fatty acids at the beginning of December $\left(5-15 \mu \mathrm{g} \mathrm{L}^{-1}\right)$ are compared with Antarctic open water values (0.1-20 $\mu \mathrm{g} \mathrm{L} \mathrm{L}^{-1}$, Fahl and Kattner 1993, Fileman et al. 1998), coastal mesotrophic water values from the Antarctic Peninsula (10 $\mu \mathrm{g} \mathrm{L}^{-1}$, Skerrat et al. 1995), a postbloom situation in Arctic waters $\left(30 \mu \mathrm{g} \mathrm{L} \mathrm{L}^{-1}\right.$, where flagellates were present, Reuss and Poulsen 2002), and the highest values of the Mediterranean Sea (1-11 $\mu \mathrm{g} \mathrm{L}^{-1}$ in winter/spring, Goutx and Saliot 1980), they clearly represent pre-bloom conditions. On the other hand, the higher fatty acid values found at the end of the cycle $\left(70-80 \mu \mathrm{g} \mathrm{L}^{-1}\right)$ resemble more those found in Greenland algae blooms (140 $\mu \mathrm{g} \mathrm{L}^{-1}$, Reuss and Poulsen 2002), and in productive Antarctic coastal waters (100 $\mu \mathrm{g} \mathrm{L}^{-1}$, Skerrat et al. 1995) or sub-surface ice waters (up to $400 \mu \mathrm{g} \mathrm{L}^{-1}$, Skerrat et al. 1995), reflecting bloom development. Our results also show a progress toward more nutritive seston (sensu Grémare et al. 2002), in which the lipid content reaches its highest values when the diatoms play a more prominent role (yet not dominating the phytoplankton biomass). The proportion (\%) of PUFAs and MUFAs corroborated this trend (Fig. 3) in which, although some markers may punctually change, the overall composition indicates a moderate-high quality of seston available for grazers, suspension feeders, deposit 
feeders and detritivores. High PUFAs and MUFAs could be interpreted as higher food availability based on the lability of their chemical structure (Goutx and Saliot 1980, Reuss and Poulsen 2002, Rossi et al. 2008). This means that the green carpets found in several Antarctic places (Gutt et al. 1998, Mincks et al. 2005, Isla et al. 2006a) may concentrate available food for the benthic fauna for long periods.

The overall bloom showed drastic fluctuations in the phytoplankton composition, which can change in only a couple of days, affecting copepod abundance, distribution and biochemical composition (Pasternak et al. 2009, Michels et al. 2012). Smith et al. (2006) suggested that there were problems to properly detect the seston pulses, because of the complex benthic topography and the near-bottom currents that may mix dead and live organic matter. Our study demonstrates that high resolution sampling may be the best tool for following such changes and estimating the availability of seston for the benthic organisms, as previously suggested for Antarctic waters (Isla et al. 2006b, Isla et al. 2009, Isla et al. 2011).

Organisms such as salps, krill, holothurians, sponges, gorgonians, and foraminifers may take advantage of surface phytoplankton blooms through a rapid assimilation process (Hopkins et al. 1993, Orejas et al. 2001, Orejas et al. 2003, Suhr et al. 2003, Hudson et al. 2004, Gili et al. 2006b, Meyer et al. 2010), especially when part of the organic matter reaches the bottom almost ungrazed in high production phases. The accumulation of fresh ungrazed material is one of the keys to understanding the high biomass and diversity of benthic communities (Mincks et al. 2005, Isla et al. 2006a, Gili et al. 2009). Hudson et al. (2004) found low levels of PUFAs prior to a spring bloom in deep-sea holothurians in contrast to those found after high surface productivity periods, when the PUFAs and specific fatty acids sharply increased, demonstrating a tight coupling of these echinoderms with phytoplankton productivity patterns in the water column.

This is (to our knowledge) the first study in which the food quality of a spring bloom has been studied from the top to bottom water layers of the Weddell Sea, including sea ice. As a concluding remark, in the present work part of the organic matter seems to be transferred from the surface to the deeper layers and practically unaltered, especially in the second half of December. Our study shows that the transport of organic matter enhanced by diatom aggregates, compaction into faecal pellets, and wind stress enhances the transfer of lipid-rich material with high nutritive quality for benthic organisms. Diatoms play a very important role in the transfer of organic matter, with high energy value, though flagellates could constitute the largest biomass of the phytoplankton community at certain times. The diatom-driven transfer of material may constitute the main food supply for the benthic community to replace the lack of fresh organic matter pulses during the autumn-winter months.

\section{ACKNOWLEDGEMENTS}

We are grateful to Carme Huguet and Susanne Fietz, who greatly improved the current version of the manuscript. We are also grateful to Jan Michels, Covadonga Orejas, Francesc Pagés, Estefanía Rodríguez, Nuria Teixidó and Begoña Vendrell-Simó for their support in the filtration lab of R/V Polarstern. We also thank the staff of R/V Polarstern for their efficient help. This study was funded by a FILANT national project (REN2003-04236, an EASIZ project). SR was financed with a Ramón y Cajal Contract (RyC-200701327) and a Beatriu de Pinós Contract (2006 BP-B1 00069).

\section{REFERENCES}

Arrigo K.R., Worthen D., Schnell A., Lizotte M.P. 1998. Primary production in Southern Ocean waters. J. Geophys. Res. 103: 15587-15600.

Asper V.L., Smith W.O. 2003. Abundance, distribution and sinking rates of aggregates in the Ross Sea, Antarctica. Deep-Sea Res. Part I 50: 131-150.

Barnes H., Blackstock J. 1973. Estimation of lipids in marine animal tissues: detailed investigation of the sulphophosphovanillin method for "total" lipids. J. Exp. Mar. Biol. Ecol. 12: 103-118.

Bathmann U., Fischer G., Müller P.J., Gerdes D. 1991. Short-term variations in particulate matter sedimentation off Kapp Norvegia, Weddell Sea, Antarctica: relation to water mass advection, ice cover, plankton biomass and feeding activity. Polar Biol. 11: $185-195$.

Caron D.A., Dennett M.R., Lonsdale D.J., Moran D.M., Shalapyonok L. 2000. Microzooplankton herbivory in the Ross Sea, Antarctica. Deep-Sea Res. Part II 47: 3249- 3272.

Chavez F.P., Buck K.R., Bidigare R.R., Karl D.M., Hebel D., Latasa M., Campbell L., Newton J. 1995. On the chlorophyll a retention properties of Glass-Fiber GF/F filters. Limn. Oceanogr. 40: 428-433.

Cripps G.C., Clarke A. 1998. Seasonal variation in the biochemical composition of particulate material collected by sediment traps at Signy Island, Antarctica. Polar Biol. 20: 414-423.

Dalsgaard J., St John M., Kattner G., Müller-Navarra D., Hagen W. 2003. Fatty acid trophic markers in the pelagic marine environment. Adv. Mar. Biol. 46: 225-340.

Fahl K., Kattner G. 1993. Lipid content and fatty acid composition of algal communities in sea-ice and water from the Weddell Sea (Antarctica). Polar Biol. 13: 405- 409.

Fileman T.W., Pond D.W., Barlow R.G., Mantoura R.F.C. 1998. Vertical profiles of pigments, fatty acids and amino acids: evidence for undegraded diatomaceous material sedimenting to the deep ocean in the Bellinghausen Sea, Antarctica. Deep-Sea Res. Part I 45: 333-346.

Folch J., Lees M., Sloane-Stanley G.H. 1957. A simple method for the isolation and purification of total lipides from animal tissues. J. Biol. Chem. 226: 497-509.

Fraser A.J., Sargent J.R., Gamble J.C., Seaton D.D. 1989. Formation and transfer of fatty acids in an enclosed marine food chain comprising phytoplankton, zooplankton and herring (Clupea harengus L.) larvae. Mar. Chem. 27: 1-18.

Gerdes D., Isla E., Knust R., Mintenbeck K., Rossi S. 2008. Response of benthic communities to disturbance: the artificial disturbance experiment BENDEX on the eastern Weddell Sea Shelf, Antarctica. Polar Biol. 31: 1469-1480.

Gili J.M., Coma R., Orejas C., López-González P.J., Zabala M. 2001. Are Antarctic suspension-feeding communities different from those elsewhere in the world? Polar Biol. 24: 473-485.

Gili J.M., Arntz W.E., Palanques A., Orejas C., Clarke A., Dayton P.K., Isla E., Teixidó N., Rossi S., López-González P.J. 2006a. A unique assemblage of epibenthic sessile suspension feeders with archaic features in the high-Antarctic. Deep-Sea Res. Part II 53 : 1029-1052. 
Gili J.M., Rossi S., Pagès F., Orejas C., Teixidó N., López-González P.J., Arntz W.E. 2006b. A new link between the pelagic and benthic systems in the Antarctic shelfs. Mar. Ecol. Prog. Ser. 322: 43-49.

Gili J.M., Orejas C., Isla E., Rossi S., Arntz W.E. 2009. Seasonality on the high Antarctic benthic shelf communities? In: J. Turner, P. Convey, G. di Prisco, P. Mayewski, D. Hodgson, E. Fahrbach, B. Bindschadler, eds. Antarctic Climate Change and the Environment. ACCE Report, Cambridge University Press, Cambridge, pp. 276-278.

Gómez-Brandón A., Lores M., Domínguez J. 2008. Comparison of extraction and derivatization methods for fatty acid analysis in solid environmental matrixes. Anal. Bioanal. Chem. 392: 505-514.

Goutx M., Saliot A. 1980. Relationship between dissolved and particulate fatty acids and hydrocarbons, chlorophyll a and zooplankton biomass in Villefranche Bay, Mediterranean Sea. Mar. Chem. 8: 299-318.

Grémare A., Medernach L., De Bovée F., Amoroux J.M., Vétion G., Albert P. 2002. Relationships between sedimentary organics and benthic meiofauna on the continental shelf and the upper slope of the Gulf of Lions (NW Mediterranean). Mar. Ecol. Prog. Ser. 234: 85-94.

Grossman S., Lochte K., Scharek R. 1996. Algal and bacterial processes in platelet ice during late austral summer. Pol. Biol. 16: 623-633.

Gutt J. 2000. Some "driving forces" structuring communities of the sublittoral Antarctic macrobenthos. Ant. Sci. 12: 297-313.

Gutt J., Starmans A. 1998. Structure and biodiversity of megabenthos in the Weddell and Lazarev Seas (Antarctica): ecological role of physical parameters and biological interactions. Pol. Biol. 20: 229-247.

Gutt J., Starmans A., Dieckmann G. 1998. Phytodetritus deposited on the Antarctic shelf and upper slope: its relevance for the benthic system. J. Mar. Syst. 17: 435-444.

Hayakawa K., Handa N., Wong C.S. 1996. Changes in the composition of fatty acids in sinking matter during a diatom bloom in a controlled experimental ecosystem. J. Exp. Mar. Biol. Ecol. 208: 29-43.

Hopkins C.C.E., Sargent J.R., Nilssen E.M. 1993. Total lipid content, and lipid and fatty acid composition of the deep-water prawn Pandalus borealis from Balsfjord, northern Norway: growth and feeding relationships. Mar. Ecol. Prog. Ser. 96: 217-228.

Howell K.L., Pond D.W., Billett D.S., Tyler M. 2003. Feeding ecology of deep-sea seastars (Echinodermata: Asteroidea): a fattyacid biomarker approach. Mar. Ecol. Prog. Ser. 255: 193-206.

Hudson I.R., Pond D.W., Billet D.S., Tyler P.A., Lampitt R.S., Wolff G.A. 2004. Temporal variations in fatty acid composition of deep-sea holoturians: evidence of bentho-pelagic coupling. Mar. Ecol. Prog. Ser. 281: 109-120.

Isla E., Rossi S., Palanques A., Gili J.M., Gerdes D., Arntz W. 2006a. Organic matter in marine sediment from the eastern Weddell Sea (Antarctica): high nutritive value in a high benthic-biomass environment. J. Mar. Sys. 60: 255-267.

Isla E., Gerdes D., Palanques A., Gili J.M., Arntz W. 2006b. Particle fluxes and tides near the continental ice edge on the eastern Weddell Sea shelf. Deep-Sea Res. Part II 53: 866-874.

Isla E., Gerdes D., Palanques A., Gili J.M., Arntz W.E., König-Langlo G. 2009. Downward particle fluxes, wind and a phytoplankton bloom over a polar continental shelf: A stormy impulse for the biological pump. Mar. Geol. 259: 59-72.

Isla E. , Homs P., Sañé E., Escribano R., Claramunt G., Teixidó N. 2010. Biochemical composition of seston in two upwelling sites within the Humboldt Current System $\left(21^{\circ} \mathrm{S}\right.$ to $\left.23^{\circ} \mathrm{S}\right)$ : Summer conditions. J. Mar. Sys. 82: 61-71.

Isla E., Gerdes D., Rossi S., Fiorillo I., Sañe E., Gili J.M., Arntz W.E. 2011. Biochemical characteristics of surface sediments on the eastern Weddell Sea continental shelf, Antarctica: is there any evidence of seasonal patterns? Pol. Biol. 34:1125-1133

Kornilova O., Rosell-Melé A. 2003. Application of microwaveassisted extraction to the analysis of biomarker climate proxies in marine sediments. Org. Geochem. 34: 1517-1523.

Kuwata A., Hama T., Takahashi M., 1993. Ecophysiological characterization of two life forms, resting spores and resting cells, of a marine planktonic diatom, Chaetoceros pseudocurvisetus, formed under nutrient depletion. Mar. Ecol. Prog. Ser. 102:
245-255.

Lampitt R.S. 1985. Evidence for the seasonal deposition of detritus to the deep-sea floor and its subsequent resuspension. Deep-Sea Res. Part I 32: 885-897.

Lee C., Fuhrman J.A. 1987. Relationship between biovolume and biomass of naturally derived marine bacterioplankton. Appl. Environm. Microb. 53: 1298-1568.

Meyer B., Auerswald L., Siegel V., Sparic S., Pape C., Fach B.A., Teschke M., Lopata A., Fuentes V. 2010. Seasonal variation in body composition, metabolic activity, feeding, and growth of adult krill Euphausia superba in the Lazarev Sea. Mar. Ecol. Prog. Ser. 398: 1-18.

Michels J., Schnack-Schiel S.B., Pasternak A., Mizdalski E., Isla E., Gerdes D. 2012. Abundance, population structure and vertical distribution of dominant calanoid copepods on the eastern Weddell Sea shelf during a spring phytoplankton bloom. Pol. Biol. 35: 369-386

Mincks S.L., Smith C.R., DeMaster D.J. 2005. Persistence of labile organic matter and microbial biomass in Antarctic shelf sediments: evidence of a sediment "food bank". Mar. Ecol. Prog. Ser. 300: 3-19.

Mincks S.L., Smith C.R., Jeffreys R.M., Sumida P.Y.G. 2008. Trophic structure on the West Antarctic Peninsula shelf: Detritivory and benthic inertia revealed by delta C-13 and delta N-15 analysis. Deep Sea Res. Part II 55: 2502-2514.

Orejas C., Gili J.M., López-González P.J., Arntz W.E. 2001. Feeding strategies and diet composition of four Antarctic cnidarian species. Pol. Biol. 24: 620-627.

Orejas C., Gili J.M., Arntz W.E. 2003. The role of small-plankton communities in the diet of two Antarctic octocorals (Primnoisis antarctica and Primnoella sp.). Mar. Ecol. Prog. Ser. 250: 105-116.

Parrish C.C. 1988. Dissolved and particulate marine lipid classes: a review. Mar. Chem. 23: 17-40.

Parrish C.C., Thompson R.J., Deibel D. 2005. Lipid classes and fatty acids in plankton and settling matter during the spring bloom in a cold ocean coastal environment. Mar. Ecol. Prog. Ser. 286: 57-68.

Pasternak A., Hagen W., Kattner G., Michels J., Graeve M., Schnack-Schiel S.B. 2009. Lipid dynamics and feeding of dominant Antarctic calanoid copepods in the eastern Weddell Sea in December. Pol. Biol. 32:1597-1606.

Prahl F.G., Eglinton G., Corner E.D.S., O'Hara S.C.M., Forsberg T.E.V. 1984. Changes in plant lipids during passage through the gut of Calanus. J. Mar. Biol. Ass. UK 64: 317-334.

Qiang H., Sommerfeld M., Jarvis E., Ghirardi M., Posewitz M., Seibert M., Darzins A. 2008. Microalgal triacylglycerols as feedstocks for biofuel production: perspectives and advances. Plant J. 54:621-639.

Reuss N., Poulsen L.K. 2002. Evaluation of fatty acids as biomarkers for a natural plankton community. A field study of a spring bloom and a post-bloom period off West Greenland. Mar. Biol. 141: 423-434.

Rossi S., Fiorillo I. 2010. Biochemical characteristics of Protoceratium reticulatum red tide progress in Chipana Bay (Northern Chile) in summer conditions. Sci. Mar. 74(4): 633-642.

Rossi S., Grémare A., Gili J.M., Amouroux J.M., Jordana E., Vétion G. 2003. Biochemical characteristics of settling particulate organic matter at two north-western Mediterranean sites: a seasonal comparison. Est. Coast. Shelf Sci. 58: 423-434.

Rossi S., Sabatés A., Latasa M., Reyes E. 2006. Lipid biomarkers and trophic linkages between phytoplankton, zooplankton and anchovy (Engraulis encrasicolus) larvae in the NW Mediterranean. J. Plank. Res. 28: 551-562.

Rossi S., Youngbluth M., Jacoby C., Pagès F., Garrofé X. 2008. Fatty acid composition and trophic links among seston, crustacean zooplankton and the siphonophore Nanomia cara in Georges Basin and Oceanographer Canyon (NW Atlantic). Sci. Mar. 72(2): 403-416.

Rossi S., Isla E., Fietz S., Martínez-García A., Sañé E., Teixidò N. 2012. Temporal variation of seston biomarkers within the Humboldt Current System off northern Chile $\left(21^{\circ} \mathrm{S}\right)$ : first simultaneous records on fatty acids, n-alkanes and GDGTs. Adv. Oceanog. Limnol. 3: 17-40.

Ruiz J., Antequera T., Andres A.I., Petron M.J., Muriel E. 2004. Improvement of a solid phase extraction method for analysis of lipid fractions in muscle foods. Anal. Chem. Acta 520: 201-205. 
Skerrat J.H., Nichols P.D., McMeekin T., Burton H. 1995. Seasonal and inter-annual changes in planktonic biomass and community structure in eastern Antarctica using signature lipids. Mar. Chem. 51: 93-113.

Smith C.R., Mincks S., DeMaster D.J. 2006. A synthesis of benthopelagic coupling on the Antarctic shelf: Food banks, ecosystem inertia and global climate change. Deep-Sea Res. Part II 53: 875-894.

Suhr S.B., Pond D.W., Gooday A.J., Smith C.R. 2003. Selective feeding by benthic foraminifera on phytodetritus on the western Antarctic Peninsula shelf: evidence from fatty acid biomarker analysis. Mar. Ecol. Prog. Ser. 262: 153-162.

Teixidó N., Garrabou J., Arntz W.E. 2002. Spatial pattern quantification of Antarctic benthic communities using landscape indices. Mar. Ecol. Prog. Ser. 242: 1-14.

Thomas D.N., Kennedy H., Kattner G., Gerdes D., Gough P., Dieckmann G.S. 2001. Biogeochemistry of platelet ice: its influence on particle flux under fast ice in the Weddell Sea, Antarctica. Pol. Biol. 24: 486-496.

Underwood G.J.C., Fietz S., Papadimitriou S., Thomas D.N., Dieckmann G.S. 2010. Distribution and composition of dissolved extracellular polymeric substances (EPS) in Antarctic sea ice. Mar. Ecol. Prog. Ser. 404: 1-19.

von Bodungen B., Nöting E.M., Sui Q. 1988. New production of phytoplankton and sedimentation during summer 1985 in the
South Eastern Weddell Sea. Comp. Biochem. Physiol. 90B: 475-487.

Scient. ed.: D. Vaqué.

Received February 28, 2013. Accepted June 5, 2013.

Published online July 30, 2013.

\section{SUPPLEMENTARY MATERIAL}

The following Tables are available through the web page http://www.icm.csic.es/scimar/supplm/sm03835SMA.pdf

TABLE S1. - Monounsaturated fatty acids and polyunsaturated fatty acids tested for differences in the extraction method (\% mean \pm SD). One-way ANOVA results for four different markers.

TABLE S2. - Fatty acid composition (as a $\%$ of the total fatty acids) in the Weddell Sea at three different depths (from 11 to 27 December 2003). Mean values and SD (standard deviation); N, Number of analysed filters per depth and day.

TABLE S3. - Fatty acid composition (as a \% of the total fatty acids) in the Weddell Sea at three different depths (from 11 to 27 December 2003). Mean values and SD (standard deviation); N, Number of analysed filters per depth and day. 